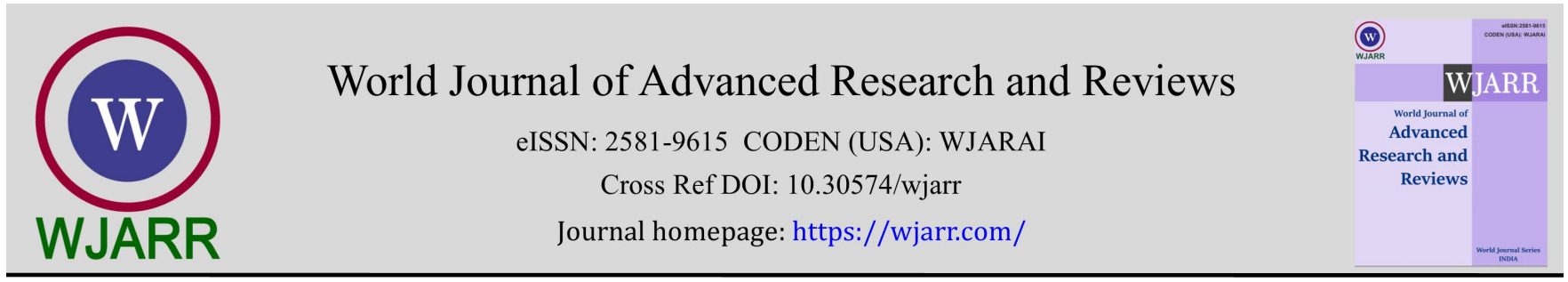

(RESEARCH ARTiCle)

\title{
Levels of some chemical species in water of boreholes situated near dumpsites in Rumuolumeni, Port Harcourt, Rivers State, Nigeria
}

\author{
Nwoke IB and Edori ES * \\ Department of Chemistry, Ignatius Ajuru University of Education Rumoulumeni, P.M.B. 5047, Port Harcourt, Rivers State, \\ Nigeria.
}

World Journal of Advanced Research and Reviews, 2021, 12(02), 202-211

Publication history: Received on 26 September 2021; revised on 06 November 2021; accepted on 08 November 2021

Article DOI: https://doi.org/10.30574/wjarr.2021.12.2.0519

\begin{abstract}
The concentration of six chemical species $\mathrm{Pb}, \mathrm{Cd}, \mathrm{As}$, nitrates, fluorides and sulphates in the groundwater (borehole) samples were investigated in four boreholes sited close to a dumpsite in Rumuolumeni, Port Harcourt, Rivers State, Nigeria. Nitrates, fluorides and sulphates were analyzed using standard conventional methods while the heavy metals were determined and analyzed with Atomic Absorption Spectrophotometer. The mean values obtained for the different chemical species within the months of investigation for the stations were in the range: lead; $0.012 \pm 0.001$ $0.015 \pm 0.000 \mathrm{mg} / \mathrm{L}$, with an average of $0.013 \pm 0.001 \mathrm{mg} / \mathrm{L}$ within the months, Cd; $0.004 \pm 0.002-0.005 \pm 0.001 \mathrm{mg} / \mathrm{L}, \mathrm{with}$ an average of $0.005 \pm 0.001 \mathrm{mg} / \mathrm{L}$ within the months, As; $0.002 \pm 0.001-0.003 \pm 0.002 \mathrm{mg} / \mathrm{L}$, with an average of $0.003 \pm 0.001 \mathrm{mg} / \mathrm{L}$ within the months, nitrates; $0.413 \pm 0.172-0.730 \pm 0.691 \mathrm{mg} / \mathrm{L}$, with an average of $0.511 \pm 0.139 \mathrm{mg} / \mathrm{L}$ within the months, fluorides; $0.004 \pm 0.001-0.006 \pm 0.001 \mathrm{mg} / \mathrm{L}$, with an average of $0.005 \pm 0.001 \mathrm{mg} / \mathrm{L}$ within the months and sulphates; $0.197 \pm 0.046-0.338 \pm 0.072 \mathrm{mg} / \mathrm{L}$, with an average of $0.290 \pm 0.055 \mathrm{mg} / \mathrm{L}$ within the months. These values obtained for the different chemical species showed that the boreholes sited near the dumpsite were still at the level that will not pose any health risk to the user, for their concentrations were still within limits allowed by WHO and USEPA. Even though the government and its agencies should regulate the mode of dumping of refuse and also the siting of boreholes so that the groundwater will not be polluted.
\end{abstract}

Keywords: Boreholes; Chemical species; Dumpsites; Groundwater; Rumuolumeni

\section{Introduction}

Indiscriminate and uncontrolled dumping of wastes in urban cities has led to the contamination, pollution and deterioration of the environments (Marcus et al., 2017) including the aquatic environment and has resulted into serious environmental challenges and concern. The increase in the contamination of surface and groundwater due to urbanization has resulted in the scarcity of potable and clean water for human consumption. Portable water is priceless and limited and it is supposed to be treasured by humans and prevent its pollution and deterioration. Humans has only come to this realization after decades of neglect on the level of water pollution and wastes that anthropogenic activities have caused (Sliderberg, 2003). An essential aspect of human life becomes generally affected due to the neglect and ignorance on the part of the populace, that good water supply is necessary and essential for healthy living and also affect human development socio-economically.

Water primarily used in the homes, industries, agricultural irrigations, commercial centres and other purposes are majorly got from underground (boreholes). The present-day activities of humans which arose as a result of advancement and urbanization led to the increase in nuclear, agricultural, biomedical, industrial and even domestic wastes which has brought about untold contamination to the groundwater and the general ecology (Momodu and

\footnotetext{
* Corresponding author: Edori ES

Department of Chemistry, Ignatius Ajuru University of Education Rumoulumeni, P.M.B. 5047, Port Harcourt, Rivers State, Nigeria.

Copyright (C) 2021 Author(s) retain the copyright of this article. This article is published under the terms of the Creative Commons Attribution Liscense 4.0
} 
Anyakora, 2010; Nwoke and Edori, 2020). Human lifestyle and behaviour coupled with the growth in population has caused the increased demand for already available land to dump refuse which is not followed up with adequate waste treatment procedure and management facilities thereby resulting in the contamination and pollution of the groundwater due to the leaching potentials of the soil. The unwholesome practices by individuals, corporate bodies, industries and factories introduces wastes and chemicals into the ecosystem. This action can be by accidental or intentional discharge and the nature of the soil has also allowed these chemicals and wastes to leach through it to the water underground which could be dangerous to human (Sunudo and Gill, 1999). The difficulty in the remediation of the contaminated groundwater and the financial burden required to restore it to the actual/normal state calls for concern (Nwoke and Edori, 2020).

The underground (borehole) water contamination by chemical species such as heavy metals, nitrates, fluorides, microorganisms etc. can affect the health status of humans who is the ultimate user of the water. These chemical species find their way into the water aquifer through leaching. Such human activities that that introduces these unwanted species to the groundwater are processing of metals, exploration, production and eventual exploitation of oil, agricultural activities, mining and through indiscriminate disposal of the by products of these human activities has added to the already overburdened situation (Adeyemi and Awokunmi, 2010; Edori et al., 2016). The manner in which the inhabitants of a particular area disposes wastes can also contribute to the level of contamination of the groundwater. The groundwater can be easily polluted through wastes, sewage and effluents that originates from homes, industries and commercial centres through percolation into the water underground.

The non-availability of data on the actual level of hazardous wastes generated and the non-reliability on the information regarding the types and quantities of waste produced and their level of toxicity in the various countries call for urgent attention and proper rethink. This is due to different reasons which include inadequate and lack of qualified manpower to properly evaluate the situation, reluctance on the part of industries to report or inform on the actual waste generated by the industries, the insincerity on the part of government and its agencies in handling waste generated, the poor appreciation on the levels of dangerous/hazardous wastes generated and the non-availability of data on the amount of wastes generated has grossly affected the ecosystem. Significantly to be noted is that where there is available data, it is also difficult to seek and draw international attention due to the difference in classification and definition of dangerous/hazardous wastes from country to country.

This paper evaluates the level of some chemical species like heavy metals ( $\mathrm{Pb}, \mathrm{Cd}, \mathrm{As})$ and chemical parameters like fluorides, nitrates and sulphates in borehole waters situated near dumpsites in Rumuolumeni, Port Harcourt, Rivers State, Nigeria.

\section{Material and methods}

Water samples were directly collected from four boreholes labelled 1, 2, 3 and 4, situated close to a dumpsite in Rumuolumeni community, Port Harcourt with the aid of 1.5 litre plastic jerry cans. The jerry cans were previously washed with soap and rinsed in distilled water and finally rinsed with the borehole water to be used for the analysis. The water samples were collected for a period of six months at intervals of two months (August, October and December) in 2020. The collected samples were immediately taken to the laboratory for the determination of some chemical species such as lead ( $\mathrm{Pb}$ ), cadmium (Cd), arsenic (As), nitrates, fluorides and sulphates. The Atomic Absorption Spectrophotometer was used in determining the concentrations of $\mathrm{Pb}, \mathrm{Cd}$ and $\mathrm{As}$, while the concentrations of nitrates, fluorides and sulphates were determined electrometrically using the ion selective or specific electrode method at a temperature range of 0 to $50^{\circ} \mathrm{C}$.

\section{Results and discussion}

\subsection{Concentrations of the Chemical Species in the different Boreholes}

The variations of the concentrations of the different chemical species investigated in the different boreholes sited close to dumpsite within the Rumuolumeni community within the months of study are provided in Tables 1 to 3 while the mean values of the chemical species within the months investigated in the different stations are given in Table 4 . The average concentrations of the chemical species in the stations at the different months are illustrated graphically in Figure 1 while the average concentration of the chemical species studied within the period of investigation are illustrated in Figure 2. 


\subsection{Lead (Pb)}

The values obtained for lead in this research was in the range $0.012-0.015 \mathrm{mg} / \mathrm{L}$ with an average of $0.014 \pm 0.001 \mathrm{mg} / \mathrm{L}$ in August, $0.011-0.015 \mathrm{mg} / \mathrm{L}$ with an average of $0.013 \pm 0.001 \mathrm{mg} / \mathrm{L}$ in October, and $0.011-0.016 \mathrm{mg} / \mathrm{L}$ with an average of $0.013 \pm 0.002 \mathrm{mg} / \mathrm{L}$ in December. The mean concentrations for the stations within the months of investigation was in the range of $0.012 \pm 0.001-0.015 \pm 0.000 \mathrm{mg} / \mathrm{L}$ with an average of $0.013 \pm 0.001 \mathrm{mg} / \mathrm{L}$. The mean concentration values recorded in this work was within the same range as required for maximum allowable limit for potable water by the WHO (2011) and USEPA (2005) of $0.015 \mathrm{mg} / \mathrm{L}$ for lead in potable water. The concentrations of lead (Pb) obtained in this work at the time of investigation was higher than that reported in the boreholes of Dumasi, Wassa West District in Ghana which was $0.005 \mathrm{ppm}$ (Obiri, 2007) and within the same range or lower than that obtained by Nwoke and Edori (2020) in the boreholes of some communities in Ikono, Akwa Ibom State, Nigeria. Lead (Pb) poses health risk to both floras and faunas at any concentration. It is poison even at trace concentrations (Edori and Edori, 2012). Pb is linked to several ailing conditions such as neurobehavioral disorder, blood poisoning and reduction in judgement, lower IQ, growth retardation, hearing and speech deformations, and unbalanced behavior in children (Hertz-Picciotto, 2000), and in adults, its effects are low sperm count, and influences abortion in women (Flora et al., 2007). The occurrence of lead in boreholes (groundwater) might have originated from the corrosion of materials used for household and industrial plumbing works, mining activities and soil leaching (EPA, 2005) and might also be from human activities like using lead laded fuels and the exploration, production and exploitation of oil (Kpee and Edori, 2014). Lead when contacted and ingested is detrimental to the health of adults, for exposure to it can result in increased pressure in the blood, cardiovascular effects, decrease in kidney functions, hypertension and reproductive challenges in both men and women (EPA, 2021)

\subsection{Cadmium (Cd)}

The values obtained for cadmium in this research was in the range $0.003-0.006 \mathrm{mg} / \mathrm{L}$ with an average of $0.005 \pm 0.001 \mathrm{mg} / \mathrm{L}$ in August, $0.002-0.006 \mathrm{mg} / \mathrm{L}$ with an average of $0.004 \pm 0.001 \mathrm{mg} / \mathrm{L}$ in October, and $0.002-0.006 \mathrm{mg} / \mathrm{L}$ with an average of $0.004 \pm 0.001 \mathrm{mg} / \mathrm{L}$ in December. The mean concentrations for the stations within the months of investigation was in the range of $0.004 \pm 0.002-0.005 \pm 0.001 \mathrm{mg} / \mathrm{L}$ with an average of $0.005 \pm 0.001 \mathrm{mg} / \mathrm{L}$. The mean concentration values recorded in this work was slightly lower or at the same level or slightly higher than the required maximum limit for potable water by the WHO (2011) and USEPA (2005) of $0.005 \mathrm{mg} / \mathrm{L}$ for cadmium in potable water. The level of cadmium obtained in this work was at the same range or far lower than that which was reported by Musa et al., (2007) which was in the range of $<0.001$ to $0.28 \mathrm{mg} / \mathrm{L}$ in boreholes and well water in Zaria, Nigeria and was at the same range or higher than that obtained by Obiri (2007) which was $0.002 \mathrm{ppm}$ in Dumasi, Wassa West, Ghana, and was also at the same range or lower than than that recorded by Nwoke and Edori (2020) in the boreholes of Ikono which ranged from not detected to $0.47 \pm 0.22 \mathrm{mg} / \mathrm{L}$. Contact or intake of inorganic chemicals such as cadmium in the environment results in poisoning and health risk, due to the toxicity of cadmium and its effect due to accumulation (Ferrer et al., 2000; Klaassen, 2000). The high occurrence of cadmium (a toxic chemical) in potable water might result in acute or chronic health challenges like vomiting, nausea, dizziness and under extreme cases results in immediate death due to large doses of cadmium and other toxic chemicals. Cadmium in water is a public health issue for its chronic effects can produce renal dysfunction, testicular necrosis, cancer, damage of the central nervous systems, arteriosclerosis, the inhibition of growth in animals and even humans and immune system damage (Klaassen, 2001; Shelton, 2002), and its effect also causes impairment of male fertility (Waalkes et al., 1992).

\subsection{Arsenic (As)}

The values obtained for arsenic in this research was in the range $0.001-0.004 \mathrm{mg} / \mathrm{L}$ with an average of $0.003 \pm 0.001 \mathrm{mg} / \mathrm{L}$ in August, $0.001-0.003 \mathrm{mg} / \mathrm{L}$ with an average of $0.002 \pm 0.001 \mathrm{mg} / \mathrm{L}$ in October, and $0.002-0.005 \mathrm{mg} / \mathrm{L}$ with an average of $0.004 \pm 0.001 \mathrm{mg} / \mathrm{L}$ in December. The mean concentrations for the stations within the months of investigation was in the range of $0.002 \pm 0.001-0.003 \pm 0.002 \mathrm{mg} / \mathrm{L}$ with an average of $0.003 \pm 0.001 \mathrm{mg} / \mathrm{L}$. The mean concentration values recorded in this work was lower than the required maximum level for potable water by the WHO (2011) and USEPA (2005) of $0.01 \mathrm{mg} / \mathrm{L}$ and $0.01 \mathrm{mg} / \mathrm{L}$ for arsenic in potable water.

The level of Arsenic (As) recorded in this work were far lower than those reported by Obiri (2007) in the boreholes of Dumasi, Wassa West Ghana which had a value of 4.52ppm. The existence of arsenic in the groundwater (borehole) constitute health challenges to humans and animals and that make use of the water and exposure to arsenic at even low levels might have significant poisonous effects (UNICEF, 2008). Arsenic is known to be an environmental pollutant that is poisonous. It possesses the potential to occur in the +5 and +3 oxidation states and can be easily absorbed into the human tract of the gastrointestinal walls (Smith and Steinmaus, 2007). Arsenicosis manifests in 2 to 20 years and it is a human disease that has slow manifestation in its occurrence. Certain diseases like hypo and hyper pigmentation, Peripheral neuropathy and peripheral vascular disease, are notable signs that manifests due to arsenic toxicity that 
affects children and adults and also reduces the development the intellects of children. The effects due to arsenic toxicity may result in skin lesion and stigmatization which may ruin the life of an individual in his developmental stages and eventually affect the entire family (UNICEF, 2013).

\subsection{Nitrates}

The values obtained for nitrates in this research was in the range $0.350-0.550 \mathrm{mg} / \mathrm{L}$ with an average of $0.425 \pm 0.083 \mathrm{mg} / \mathrm{L}$ in August, $0.520-1.700 \mathrm{mg} / \mathrm{L}$ with an average of $0.933 \pm 0.465 \mathrm{mg} / \mathrm{L}$ in October, and $0.140-0.170 \mathrm{mg} / \mathrm{L}$ with an average of $0.155 \pm 0.011 \mathrm{mg} / \mathrm{L}$ in December. The mean concentrations for the stations within the months of investigation was in the range of $0.413 \pm 0.172-0.730 \pm 0.691 \mathrm{mg} / \mathrm{L}$ with an average of $0.511 \pm 0.139 \mathrm{mg} / \mathrm{L}$. The mean concentration values recorded in this work was far lower than the required maximum concentration for potable water by the WHO (2011) and USEPA (2005) of 50mg/L and 10mg/L for fluorides in potable water. The values recorded in this investigation were lower than that reported by Alex et al., (2021) from groundwater aquifers in Tanzanian semiarid regions which values were in the range of 2.4 to $929.6 \mathrm{ppm}$ in the dry season and 2.4 to $1620.0 \mathrm{ppm}$ in the wet season and those of Stuart et al., (2008) in Morestead Karehhole Twyfordwhich was 18mg N/L in unsaturated zone and 9mg $\mathrm{N} / \mathrm{L}$ in saturated zone. The presence of nitrates in drinking water especially underground (boreholes) systems is of utmost worry due to the fact that they are private and most often does not meet standard regulated by relevant agencies set by the various governments of the world. It is the responsibility of the individual owners to test and treat their personal borehole waters for pollutants such as nitrates. Nitrates do not occur naturally in groundwater and levels higher than 3mg/L actually show contamination (Madison and Brunett, 1985) and recent studies worldwide have proved that concentration above $1 \mathrm{mg} / \mathrm{L}$ of nitrate is an evidence of anthropogenic activity (Dubrovsky et al., 2010). For the protection of blue-baby syndrome EPA has kept the maximum level of nitrate contamination at $10 \mathrm{mg} / \mathrm{L}$. One of the most common global contaminant of groundwater and surface water is nitrate (Chen et al., 2016; Anornu et al., 2017). Nitrates has very high solubility in water and also easily adsorbed to the soil and leaches at ease thereby increasing its concentration in the groundwater system and sources (Elisante and Muzuka, 2017). The increase in concentration of nitrates in groundwater system (boreholes) poses significant danger to water resources due to its effect in compromising the quality of water (Tredoux et al., 2009; Chen et al., 2016). High concentration of nitrates in water and food is a serious threat to human health for nitrates concentrations has relationship with stomach cancer, hypertension, methemoglobinemia and gastrointestinal cancers in new born infants (Foley et al., 2012; Vasanthavigar and Srinivasamoorthy, 2012). High level of nitrate in the aquatic ecosystem may cause enrichment of nutrients that can lead to eutrophication therby affecting the general ecosystem and degradation of the water quality (Burns et al., 2009; Weigelhofer et al., 2018).

\subsection{Fluorides}

The values obtained for fluorides in this research was in the range $0.005-0.007 \mathrm{mg} / \mathrm{L}$ with an average of $0.006 \pm 0.001 \mathrm{mg} / \mathrm{L}$ in August, $0.002-0.005 \mathrm{mg} / \mathrm{L}$ with an average of $0.004 \pm 0.001 \mathrm{mg} / \mathrm{L}$ in October, and $0.003-0.008 \mathrm{mg} / \mathrm{L}$ with an average of $0.005 \pm 0.002 \mathrm{mg} / \mathrm{L}$ in December. The mean concentrations for the stations within the months of investigation was in the range of $0.004 \pm 0.001-0.006 \pm 0.001 \mathrm{mg} / \mathrm{L}$ with an average of $0.005 \pm 0.001 \mathrm{mg} / \mathrm{L}$. The mean concentration values recorded in this work was far lower than the required maximum concentration for potable water by the WHO (2011) and USEPA (2005) of $1.5 \mathrm{mg} / \mathrm{L}$ for fluorides in potable water. The values recorded in this investigation was also lower than that reported by Ram et al., (2017) from water samples obtained from Navi Mumbai, Maharashtra, India. The possible sources of fluoride in the boreholes might possibly be through the leaching of the waste dumps or through chemicals used for the treatment of the borehole waters. Fluorides is essential in protecting the teeth from decay and weakening of the bones. At higher concentration fluorides have more adverse effects. The concentration of fluorides in potable water is a vital parameter and there is need for it to be controlled in order to prevent skeletal and dental fluorosis (Chandio et al., 2015). About 200 million individuals in over 25 countries of the world are at risk of health challenges resulting from the high level of fluorides in water for domestic use (Amouei et al., 2012; Ayoob and Gupta, 2006). Studies have shown that the consumption of water that has high concentration ( $>4 \mathrm{mg} / \mathrm{L}$ ) of fluoride for a long time may lead to many devastating effects on humans which include skeletal and dental fluorosis. Due to these effects, the WHO set the standard level of fluoride in potable/drinking water to be in the range of $0.5-1.5 \mathrm{mg} / \mathrm{L}$ (Amouei et al., 2012; Meenakshi and Maheshwari, 2006; WHO, 2006; Singh et al., 2007). Trace quantities of fluoride ion in water for drinking purposes helps in the growth and development of the bones and the teeth (Rajkovic et al., 2007). Fluorides presence in potable water is a factor that strongly affects and influences the global dental care situation. The monitoring of the level of fluorides in potable/drinking water is necessary in achieving the safety required (Japlap et al., 2012). 


\subsection{Sulphates}

The values obtained for sulphates in this research was in the range $0.234-0.561 \mathrm{mg} / \mathrm{L}$ with an average of $0.385 \pm 0.120 \mathrm{mg} / \mathrm{L}$ in August, $0.225-0.411 \mathrm{mg} / \mathrm{L}$ with an average of $0.327 \pm 0.069 \mathrm{mg} / \mathrm{L}$ in October, and $0.132-0.241 \mathrm{mg} / \mathrm{L}$ with an average of $0.192 \pm 0.046$ in December. The mean concentrations for the stations within the months of investigation was in the range of $0.197 \pm 0.046-0.338 \pm 0.072 \mathrm{mg} / \mathrm{L}$ with an average of $0.290 \pm 0.055 \mathrm{mg} / \mathrm{L}$. The mean concentration values recorded in this work was far lower than the required maximum level for potable water by the WHO (2011) and USEPA (2005) of 400mg/L for sulphate. The level of sulphate recorded in this research was within the same range reportedly obtained by Edori and Kpee (2016) in selected boreholes sited in abattoirs within the Port Harcourt Metropolitan city where Sulphate concentrations were all below $1.00 \mathrm{mg} / \mathrm{L}$ in the stations sampled. The recorded results for sulphates in this study were lower than that obtained by Edori et al., (2020) from the surface water of the Elelenwo River that had a range of 747.333 $\pm 24.253-757.000 \pm 33.146 \mathrm{mg} / \mathrm{L}$. The occurrence of sulphate in the boreholes (water) possibly might be due to geologic foundation of the soil type, the percolation, penetration and also the leaching of waste from the dumpsites over the soil strata (Adisa, 2012; Edori and Edori, 2012). The methods that can remove sulphates from water are electrodialysis or reverse osmosis and distillation and both methods are very expensive. The presence of sulphate in water to level of 500-700mg/L might pose significant health challenges in humans and add taste to water but its presence at lower concentration of about $300 \mathrm{mg} / \mathrm{L}$ may not pose any danger or add taste. Certain side effects due to the intake of sulphate by humans include intestinal disorder, catharsis and loss of water from the body. These effects have been linked to high concentration of sulphate in water consumed by humans for domestic or other uses (Bertram and Balance, 1996). Very high concentration of sulphate in aquatic setting have the possibility of reducing the water $\mathrm{pH}$ and thereby resulting in the proliferation of bacteria within the aquatic system.

Table 1 Concentrations of the Chemical Species in the Different Boreholes Situated near Dumpsites in Rumuolumeni in August

\begin{tabular}{|l|c|c|c|c|c|}
\hline \multirow{2}{*}{ Parameter (mg/L) } & \multicolumn{4}{|c|}{ Stations } & \multirow{2}{*}{ Station Mean } \\
\cline { 2 - 5 } & $\mathbf{1}$ & $\mathbf{2}$ & $\mathbf{3}$ & $\mathbf{4}$ & \\
\hline $\mathrm{Pb}$ & 0.014 & 0.013 & 0.012 & 0.015 & $0.014 \pm 0.001$ \\
\hline $\mathrm{Cd}$ & 0.005 & 0.003 & 0.006 & 0.004 & $0.005 \pm 0.001$ \\
\hline $\mathrm{As}$ & 0.001 & 0.003 & 0.004 & 0.003 & $0.003 \pm 0.001$ \\
\hline Nitrates & 0.450 & 0.350 & 0.550 & 0.350 & $0.425 \pm 0.083$ \\
\hline Fluorides & 0.005 & 0.007 & 0.005 & 0.006 & $0.006 \pm 0.001$ \\
\hline Sulphates & 0.234 & 0.412 & 0.333 & 0.561 & $0.385 \pm 0.120$ \\
\hline
\end{tabular}

Table 2 Concentrations of the Chemical Species in the Different Boreholes Situated near Dumpsites in Rumuolumeni in October

\begin{tabular}{|l|c|c|c|c|c|}
\hline \multirow{2}{*}{ Parameter (mg/L) } & \multicolumn{3}{|l|}{ Stations } & \multirow{2}{*}{ Station Mean } \\
\cline { 2 - 5 } & $\mathbf{1}$ & $\mathbf{2}$ & $\mathbf{3}$ & $\mathbf{4}$ & \\
\hline $\mathrm{Pb}$ & 0.013 & 0.014 & 0.011 & 0.015 & $0.013 \pm 0.001$ \\
\hline $\mathrm{Cd}$ & 0.002 & 0.006 & 0.003 & 0.004 & $0.004 \pm 0.001$ \\
\hline $\mathrm{As}$ & 0.002 & 0.003 & 0.002 & 0.001 & $0.002 \pm 0.001$ \\
\hline Nitrates & 0.900 & 1.700 & 0.520 & 0.610 & $0.933 \pm 0.465$ \\
\hline Fluorides & 0.004 & 0.004 & 0.002 & 0.005 & $0.004 \pm 0.001$ \\
\hline Sulphates & 0.225 & 0.360 & 0.411 & 0.312 & $0.327 \pm 0.069$ \\
\hline
\end{tabular}


Table 3 Concentrations of the Chemical Species in the Different Boreholes Situated near Dumpsites in Rumuolumeni in December

\begin{tabular}{|l|c|c|c|c|c|}
\hline \multirow{2}{*}{ Parameter (mg/L) } & \multicolumn{4}{|c|}{ Stations } & \multirow{2}{*}{ Station Mean } \\
\cline { 2 - 5 } & $\mathbf{1}$ & $\mathbf{2}$ & $\mathbf{3}$ & $\mathbf{4}$ & \\
\hline $\mathrm{Pb}$ & 0.012 & 0.011 & 0.013 & 0.016 & $0.013 \pm 0.002$ \\
\hline $\mathrm{Cd}$ & 0.004 & 0.002 & 0.005 & 0.006 & $0.004 \pm 0.001$ \\
\hline As & 0.005 & 0.004 & 0.002 & 0.003 & $0.004 \pm 0.001$ \\
\hline Nitrates & 0.160 & 0.140 & 0.170 & 0.150 & $0.155 \pm 0.011$ \\
\hline Fluorides & 0.005 & 0.003 & 0.004 & 0.008 & $0.005 \pm 0.002$ \\
\hline Sulphates & 0.132 & 0.241 & 0.232 & 0.161 & $0.192 \pm 0.046$ \\
\hline
\end{tabular}

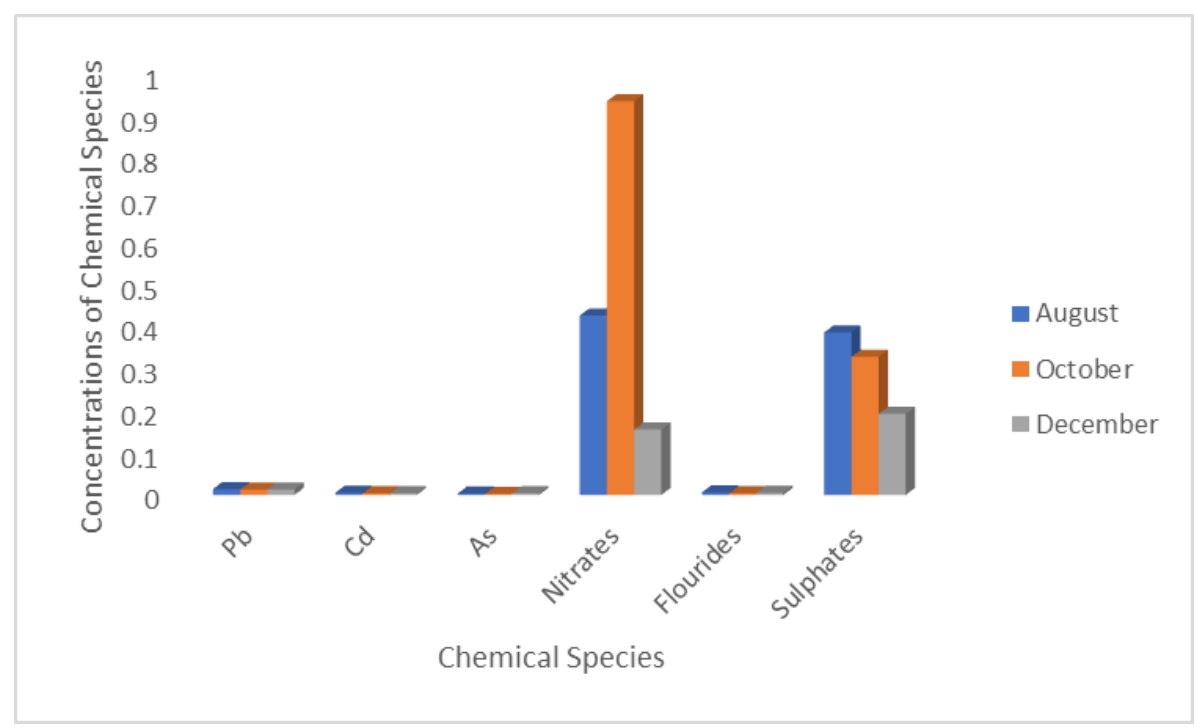

Figure 1 Mean Concentrations of Chemical Species in the different Boreholes (Stations) situated near dumpsites in Rumuolumeni within the Months of Investigation

Table 4 Mean Concentrations of the Chemical Species in the Different Boreholes Situated near Dumpsites in Rumuolumeni in the Studied Months

\begin{tabular}{|l|c|c|c|c|}
\hline \multirow{2}{*}{ Parameter (mg/L) } & \multicolumn{4}{|c|}{ Stations } \\
\cline { 2 - 5 } & $\mathbf{1}$ & $\mathbf{2}$ & $\mathbf{3}$ & $\mathbf{4}$ \\
\hline $\mathrm{Pb}$ & $0.013 \pm 0.001$ & $0.013 \pm 0.001$ & $0.012 \pm 0.001$ & $0.015 \pm 0.000$ \\
\hline $\mathrm{Cd}$ & $0.004 \pm 0.001$ & $0.004 \pm 0.002$ & $0.005 \pm 0.001$ & $0.005 \pm 0.001$ \\
\hline $\mathrm{As}$ & $0.003 \pm 0.002$ & $0.003 \pm 0.001$ & $0.003 \pm 0.001$ & $0.002 \pm 0.001$ \\
\hline Nitrates & $0.503 \pm 0.304$ & $0.730 \pm 0.691$ & $0.413 \pm 0.172$ & $0.370 \pm 0.188$ \\
\hline Fluorides & $0.005 \pm 0.000$ & $0.005 \pm 0.002$ & $0.004 \pm 0.001$ & $0.006 \pm 0.001$ \\
\hline Sulphates & $0.197 \pm 0.046$ & $0.338 \pm 0.072$ & $0.325 \pm 0.073$ & $0.298 \pm 0.150$ \\
\hline
\end{tabular}




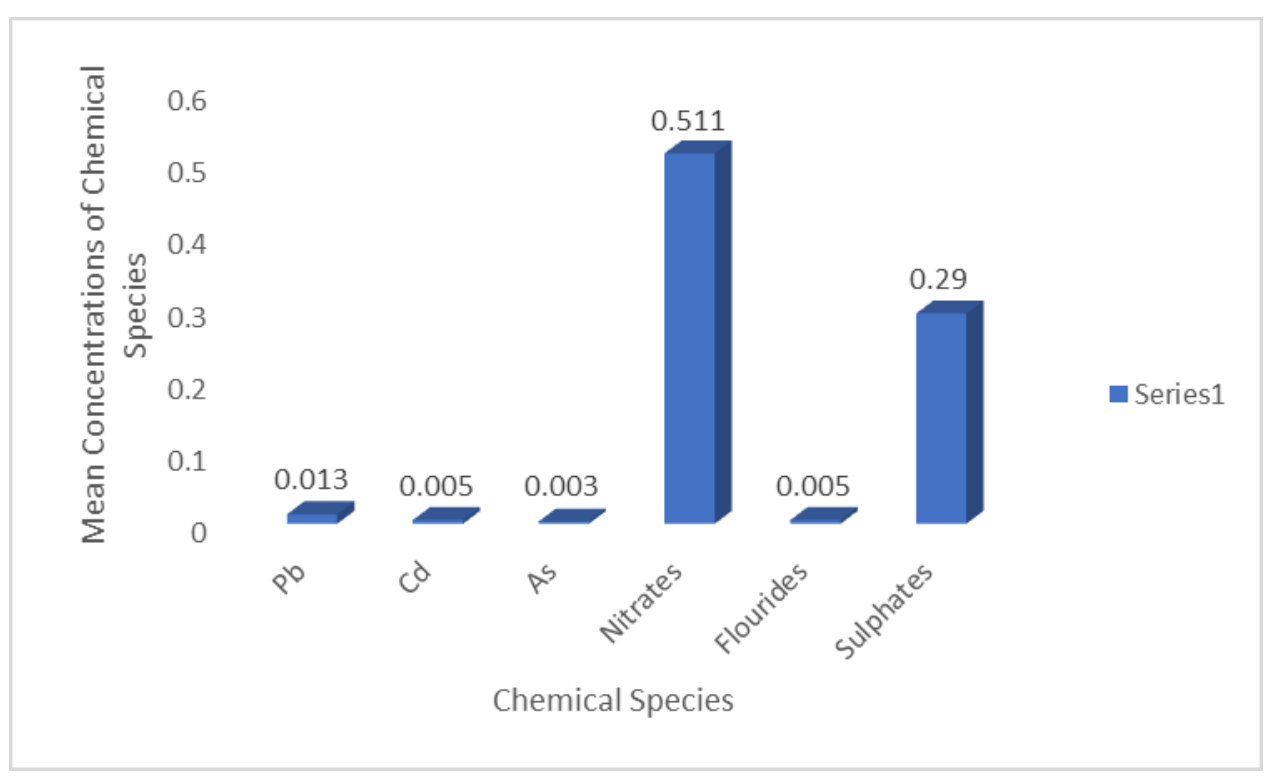

Figure 2 Mean Level of Chemical Species in the Period (August - December) under Investigation in the Stations (Boreholes)

\section{Conclusion}

The contamination of chemical species $(\mathrm{Pb}, \mathrm{Cd}, \mathrm{As}$, nitrates, fluorides and Sulphates) in the selected boreholes (groundwater) of the Rumuolumeni, Port Harcourt, Nigeria close to a dumpsite were still within acceptable limits required by international bodies such as the WHO and the USEPA for water used for drinking and other domestic activities. The values obtained revealed that the boreholes were not affected grossly by the dumpsite for the concentration ranges of the chemical species were still low as compared to other boreholes outside the region of investigation. The borehole waters were still good for human consumption although it is required that boreholes should not be sited close to a dumpsite for, there is the possibility that at a critical time the soil may not be able to prevent the leaching of these chemical species from leaching underground to the water levels of the borehole and hence increase in concentration to a level that will not be acceptable for human consumption.

\section{Compliance with ethical standards}

\section{Acknowledgments}

The Department of Chemistry of Ignatius Ajuru University is well Acknowledged for providing their laboratory.

\section{Disclosure of conflict of interest}

No conflict of interest exists.

\section{References}

[1] Adisa MJ, Agwuncha CS, Mohammed GF. Physicochemical and bacteriological analysis of underground water in Laipai (LGA) Niger State of Nigeria. Proceedings of the 35th Annual Int. Conf. Workshop and Exhibition of Chemical Society of Nigeria. 2012; 1: 170-174.

[2] Alex R, Kitalika A, Mogusu E, Njau K. Sources of nitrates in groundwater aquifers of the semiarid region of Tanzania. Geofluids. 2021.

[3] Amouei A, Mahvi AH, Mohammadi AA, Asghamia HA, Fallah SH, Khafajeh AA. Fluoride concentration in potable groundwater in rural area of Khaf City, Razavi Khorasan Province Northeastern Iran. International Journal of Occupational and Environmental Medicine. 2012; 3: 201-203. 
[4] Anornu G, Gilbrilla A, Adomako D. Tracking nitrate sources in groundwater and associated health risk for rural communities in the White Volta River Basin of Ghana using isotopic approach. Technical Report. Science of the Total Environment. 2017.

[5] Adefemi OS, Awokunmi EE. The impact of municipal solid waste disposal in Ado-Ekiti metropolis, Ekiti State, Nigeria. African Journal of Environmental Science and Technology. 2009; 3(8): 186-191.

[6] Ayoob S, Gupta AK. Fluoride in Drinking water. A review on the status and stress effects. Critical Reviews on Environmental Science and Technology. 2006; 36: 433-487.

[7] Bertram J, Balance R. A Practical guide to the design and implementation of freshwater, quality studies and monitoring programmes. Published on behalf of United Nations Environmental Programme (UNEP) and World Health Organization (WHO), E \& F. N. Spoon Publishers. 1996; 172 -177, 192-196.

[8] Burns D, Boyer EW, Elliot EM, Kendall C. Sources and transformations of nitrate from streams draining varying land uses: evidence from dual isotope analysis. Journal of Environmental Quality. 1996; 38: 1149-1159.

[9] Chandio TA, Khan MN, Sarwar A. Fluoride estimation and its correlation with other physicochemical parameters in drinking water of some areas of Balosclustan, Pakistan. Environmental Monitoring and Assessment. 2015; 187: 531.

[10] Chen J, Wu H, Qian H, Gao Y. Assessing nitrate and fluoride contaminants in drinking water and their health risk of rural residents living in a semiarid region of Northwest China, no 126. Exposure and Health, Springer, Netherlands. 2016.

[11] Dubovsky NM, Burow KR, Clark G, Gronberg JM, Hamilton PA, Hitt KJ, Mueller DK, Munn MD, Nolan BT, Pucket LJ, Rupert MG, Short TM, Spahr NE, Sprague LA, Wilber Wg. The quality of our Nations' streams and groundwater. 1992-2004: US Geological Survey Circular. 2010; 1350.

[12] Edori OS, Edori ES. Effect of Automechanic works on lead and iron in two mechanic villages in Port Harcourt, Rivers State Nigeria. Journal of Applied Science and Environmental Management. 2012; 16(4): $317-321$.

[13] Edori OS, Iyama WA, Amadi MC. Status of heavy metals contamination in water from the Elelenwo River, ObioAkpor, Rivers State, Nigeria Direct Research Journal of Chemistry and Material Science. 2019; 6(3): 25-31.

[14] Edori OS, Kpee F. Physicochemical and Heavy Metal Assessment of Water Samples from Boreholes near Some Abattoirs in Port Harcourt, Rivers State, Nigeria American Chemical Science Journal. 2016; 14(3): 1-8.

[15] Elisante E, Muzuka ANN. Occurrence of nitrate in Tanzanian groundwater aquifers: a review: Applied Water Science. 2017; 1-17.

[16] United States Environmental Protection Agency (EPA) (2005). Groundwater current standards. National Primary Drinking Water Standards. 2005; 1-12.

[17] United States Environmental Protection Agency (EPA) (2021). Groundwater current standards. National Primary Drinking Water Standards. 2021; 1-16.

[18] Ferrer L, Contardi E, Andrade SJ, Asteasuain R, Pucci AE, Marcovecchio JE. Environmental cadmium and lead concentrations in the Bahia Blanca (Argentina): potential toxic effects of $\mathrm{Cd}$ and $\mathrm{Pb}$ on $\mathrm{Crab}$ and larvae. Oceanologia. 2000; 42: 494-504.

[19] Flora SJS, Saxena G, Gautam P, Kaur P, Gill KD. Lead induced oxidative stress and alterations in biogenic amines in different rat brain regions and their response to combined administration of DMSA and MADMSA. Chemical and Biological Interactions. 2007;170: 209-220.

[20] Foley KM, Doniger R, Shock CC, Hornneck DA, Welch TK. Nitrate pollution in groundwater: sustainable Agriculture Techniques, Oregon State University in Department of Crop and Soil Science. A Growe's Guide Ext/Crs. 2012; 137: 1-8.

[21] Hertz-Picciotto I. The evidence that lead increases the risk for spontaneous abortion. American Journal of Industrial Medicine. 2000; 38: 300-309.

[22] Jagtap S, Yenkie MK, Labhsetwar N, Rayalu S. Fluoride in drinking water and defluoridation of water. Chemical Reviews. 2012; 112: 2454-2466.

[23] Kpee F, Edori OS. Trace metals content in shore crabs (Cardisoma guanhumi) from coastal area of Port Harcourt City, Rivers State, Nigeria. Archives of Applied Science Research. 2014; 6(6):16-21. 
[24] Madison RJ, Brunett JO. Overview of the occurrence of nitrates in groundwater of United States, in national water summary 1984 Hydrologic Events, selected water quality. Trends, and groundwater resources: U.S. Geological Survey, water supply paper. 1985; 2275: 93-105.

[25] Marcus AC, Nwineewii JD, Edori OS. Heavy metals assessment of leachate contaminated soils from selected dumpsites in Port Harcourt, Rivers State, South-South, Nigeria. International Journal of Chemical Studies. 2017; 5(6): 1507-1511.

[26] Meenakshi, Maheshwari RC. Fluoride in drinking water and its removal. Journal of Hazardous Materials. 2006; 137: 456-463.

[27] Momodu M, Anyakora C. Heavy metal contamination of groundwater; the Surulere case study. Research Journal of Environmental Earth Science. 2010; 2(1): 29-43.

[28] Musa H Yakasai, IA Musa, HH Musa KY, Gwarzo MS. The concentration of cadmium in borehole and well waters in Zaria, Nigeria. Journal of Applied Sciences. 2007; 7: 3572-3575.

[29] Nwoke IB, Edori ES. Concentration of heavy metals in borehole water from Ikono Urban, Ikono Local Government Area, Akwa Ibom State, Nigeria. International Journal of Advanced Research in Chemical Sciences. 2020; 7(1): 27-33.

[30] Obiri S. Determination of heavy metals in water from boreholes in Dumasi in the Wassa West District of western region of Republic of Ghana. Environmental Monitoring and Assessment. 2007; 130(1-3): 455-463.

[31] Rajkovic MB, Novakovic ID. Determination of fluoride content in drinking water and tea infusions using fluoride ion selective electrode. Journal of Agricultural Science. 2007; 52: 155-158.

[32] Ram SM, Thakker VP, Machele P. Determination of fluoride level in drinking water from water samples in Navi Mumbai, Maharashtra. Journal of Indian Association of Public Health and Dentistry. 2017; 15: 395-398.

[33] Shelton TB. Interpreting drinking water quality analysis. What do the number mean? Putgers Cooperative Extension, New Jersey, USA. 2002.

[34] Sindayigaya ERV, Cauwnbergh, H Robberecht, Deelstra H. 1994. Copper, zinc, manganese, iron, lead, cadmium, mercury, and arsenic in fish from Lake Tanganyika, Burundi. Science and Total Environment. 1994; 144: 103115.

[35] Singh B, Gaur S, Gang, VK. Fluoride in drinking water and human urine in Southern Haryana, India. Journal of Hazardous Materials. 2007; 144: 147-151.

[36] Sliderberg MS. Higher Education Chemistry. The molecular nature of matter and change; London McGraw Hill. 2003.

[37] Smith A, Steinmaus C. High concentrations of arsenic in drinking water results in the highest known increase in mortality attributes to any environmental exposure. In: Paper presented at the "Arsenic in drinking water a global threat to health" sessions of the Royal Geographic Society Annual Conference. 2007.

[38] Stuart ME, Chilton PJ, Newell AJ, Butcher AS. Nitrate concentrations in the Morestead Karehole, Twyford. British Geological Survey. 2008; 53.

[39] Sunudo-Wilhelmy SA, Gill GA. Impact of the clean water act on the levels of toxic metals in urban estuaries, the Hudson River estuary revisited. Environmental Science and Technology. 1999; 33: 3471-3481.

[40] Suthar S, Bishnoi P, Singh S, Mutiyar PK, Nema AK, Patil NS. Nitrate contamination in groundwater of some rural areas of Rajasthan, India. Journal of Hazardous Materials. 2009; 171(1-3): 189-199.

[41] Tredoux G, Engelbrecht P, Israel S. Nitrate in groundwater why is it a hazard and how to control it? Water Research Commission Report 8. 2009.

[42] UNICEF. Arsenic mitigation in Bangladesh. 2008.

[43] UNICEF. Arsenic contamination in groundwater. 2013.

[44] United States Environmental Protection Agency (EPA, 2005). Groundwater current standards. National Primary Drinking Water Standards.

[45] Vasanthavigar M, Srinivasamoorthy K. Characterization and quality assessment of groundwater with a specialemphasis on irrigation utility: Thirmanimittar sub-basin, Tamil Nadu, India. Arab Journal Geoselence. 2012; 5(2): 244-258. 
[46] Waalkes MP, Coogan TP, Barter RA. Toxicological principles of metal carcinogenesis with special emphasis on cadmium. Critical Review and Toxicology. 1992; 22: 175-201.

[47] Weigelhofer G, Hein J, Bondar-Kunze E. Phosphorus and nitrogen dynamics in riverine systems: Human impacts and management options in riverine ecosystem management, S, Schmitz and J. Sendzimir, Eds, vol. 8 of Aquatic Ecology Series, Springer, Cham. 2018; 187-202.

[48] WHO. Guidelines for drinking water quality. 4th ed. Geneva: World Health Organization. 2006.

[49] WHO. Guidelines for drinking water quality. 4th ed. Geneva: World Health Organization. 2011. 